Fig. $\quad 2$

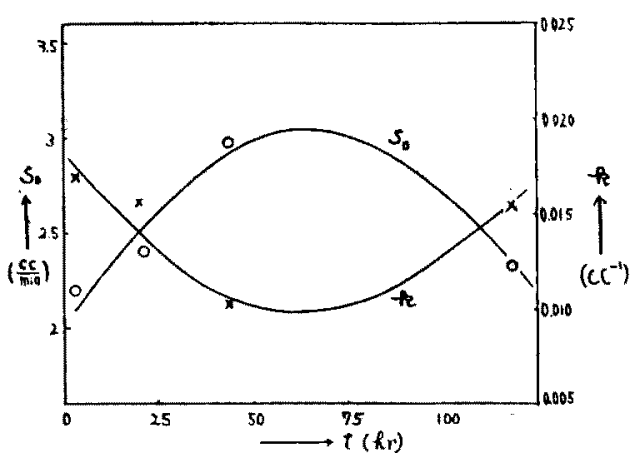

惯䮑の結果，濾過材料に紡糸口金を用いた場合と， 濾布を用いた場合とその趣が暴なり，この結果からる 两者の目の閉塞機棈の相遠が窥かれる。先ず第 1 圖似 紡系口金を使用した場合の結果をみると，Kは熟成初 期上昇して概ね最低粘度點附近で最大となり，その後 は次第に下降する。๙は熟成初期急速に減少し最低粘

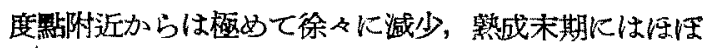

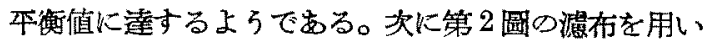
た場合には $S_{o}$ は第 1 圖の $K$ とほ注並行的な變化を 示しているが， $k$ の變化は $\alpha$ と異なり，熟成初期の 減少は $\alpha$ と同樣でむるが， $k$ Kは極少值が存在し， 熟成末期化再び增大する。

熟成間のビスコースの溶解狀態の縓化としては熱成 初期は分散溶解の進行過程，換言すると粗分散加ら微 分散への篮化，熟成中期以後はザントゲン基の離晥の ための分子間相互作用の垍加による 2 次的棈造の形成 が考えられている。從つて本賽驗の結果, 紡系口金を 使用した場合は濾過性を支配するものは主として1次

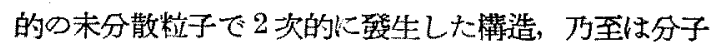
會合體等は滤過の障害にはならないものと考穴られる。

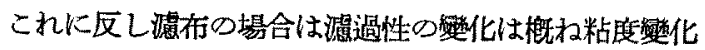
と並行關係にあり，2次的に登生し太榡造，組織にも 影製されるものと推定される。故に源過度を測定する にあたり，濾過材料に紡糸口金を使用する場合には一 定期間熟成後はほぼ一樣の結果が得られるが, 㴓布等 を使用する場合は熟成時間により異つた結果となるこ とは注意すべきことでする。

\section{IV 總括}

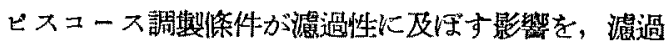
材料にスフ用紡系口金と憈布を用いて检討し次の結果 を得た。

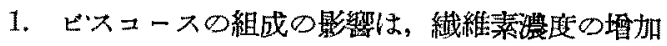

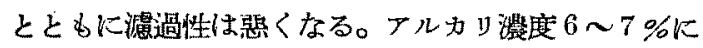

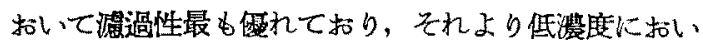

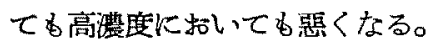

2. アルカリ䋐維素の老成はビスコースの濾過性を 向上し，無老性のビスュースは腹過困難でする。

3. ピスコース熟成の影響は濾過材料によつて異る。 紡糸口金を使用した場合は熟成の淮行とをもに濾過性 は良好となり，熟成中期以後放んど綨化しない。滤布 等を使用した場合は最低粘度點附近で最も良好でむる。 文献

1) O. Samuelson, Svensk Papperstidn, 48, 517 (1945)

2) H. A. Wannow, Ray. Synth. Zell., 29, 135 (1951)

本研究の一部は日本化學會第 5 年會 (昭27-4)

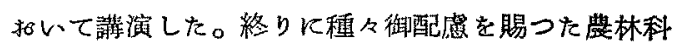
學研究所長岡田元氏，虽所第 2 部長前田弘邦氏几感 謝する。

經系誫力管理の實用的效果について

第 1 報 緒言並びに工大式經糸張力指示裝置について

東京工業大學 內田豐作・久世策一

\section{1. 緒言}

製織中の經系張力の棃化の狀態とか, 大きさの程度
が色々の意味で製品の品質に對して密接な關俰を有す るものであるといらことは, 從來からしばしば諭議さ

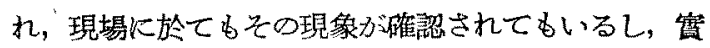


驗的硎究りる種々行われていることは周知の通りで㟧

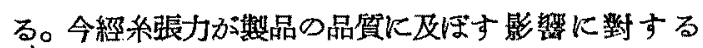
考察を大別乙てみると，次の如くなるるのと思われ る。

（1）個々の經級は引通し幅を部分的に分けて考え

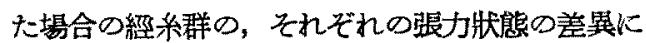
基ずく影留。

(2) 全經糸張力の狀態の相異に基ずく影劉

一般に製織中に招いては(1)及び(2)の現象は多かれ少 かれ存在するるのだするが，均望な織物を得るには出 来るたこけこれ等の影垔を除かねばならない。

(1)の如き經系張力の狀態は主として個々の系の彈性 の不均一性並に整經, 經契の不注意によつて生ずるる のでり，又經系といらるのは可成りの幅を以て多数 のものが可成りの長さの區間に張つているものでる という本質的な境界條件比よつて生ずるすのですると の考え方をすれば力學的, 物理的に云つて織機の調箅 のみでこの現象を防ぐことは不可能で，紡䖽，整系， 製織淮菕等の工程に於て事前に對策されるべきであつ て，このため製品は織段，織垃等の織揘や風合の點て
少なからざる影響を受けるるのと考えられる。

一方(2)の現象は同じ織物を多数の織機で織る場合と か，一臺の織機で同じ織物を大量に作る場合に問題に なるすのでこれれによつて織物は主として繶蹜み等の

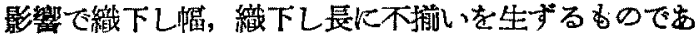
ると共に，(1)の場合と同䇐風合の點でも可成りの影贸 を與えるものと考えられる。しかして，このような經 糸張力狀態は周知の如〈織機の䢪出，然取，開口等の 䗬動狀態の不良とか相違によつて生ずるるのであるか ら，蟣機の調節さえ完全なるのとすれば充分防ぎ得る ஆのである

從つて蟣機の經系張力自動調節は主として(2)の現象 を防止することを主目的として行らことが最も穻當て 宁り，多くの織機は機棈的にはこの目的に可成り適し たるのとなつている。

以上の如き考察を熵附ける意沬で著者は最近磁歪型 張力計2)によつて，同じ織物を作つている同一型式の 多数の織機についてそれぞれの經糸張力狀態を現場で

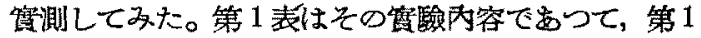
圖に示す如く上記張力計の篹換器を織機上に装置して,
第

\begin{tabular}{|c|c|c|c|c|c|}
\hline 繶樴 の種類 & 測 定 鲒 數 & $\begin{array}{c}\text { 縕機本均回輞数 } \\
\text { (r.p.m.) }\end{array}$ & 織 物 の種 類 & 測定稚禾本数 & $\begin{array}{c}\text { 测定 位置 } \\
\text { (左耳ょり }\end{array}$ \\
\hline A 自動蟣機 & 50 & 160 & 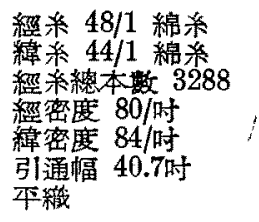 & 4 & $10 \sim 20$ \\
\hline B 毛緎機 & 12 & 90 & 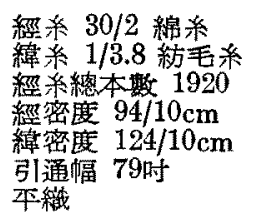 & 4 & $70 \sim 90$ \\
\hline C 毛緒 機 & 8 & 85 & 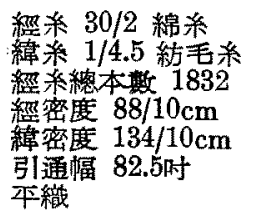 & 4 & $75 \sim 90$ \\
\hline D 毛織穖 & 6 & 90 & 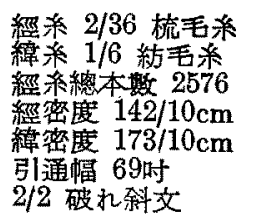 & 8 & $55 \sim 80$ \\
\hline
\end{tabular}


Fig. 1

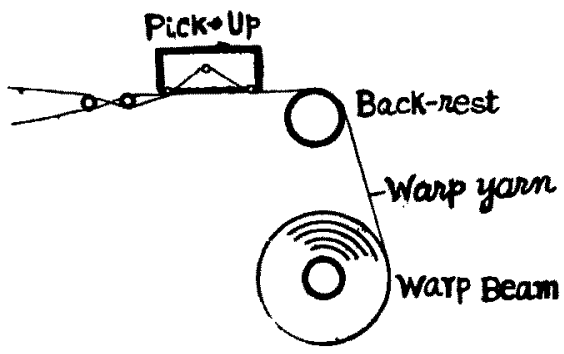

4〜8本の經糸につ、て雚測した。

直流記錄電流計で得た多數の記錄の代表的なるのを 示したのが第 2 圖〜第 3 圆であつて，前者は主として

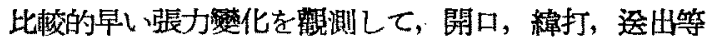
の機能を考察するため，可成り大きな速度（每分 240 $\mathrm{mm}$ ）で記錄紙を送つて求めたるの，後者は远出，突 取等の影響によつて長時間に亘る經糸張力の狀態が如

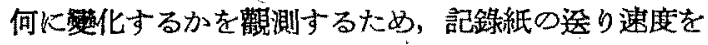

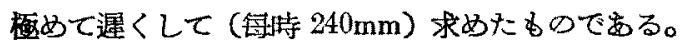

Fig. 2

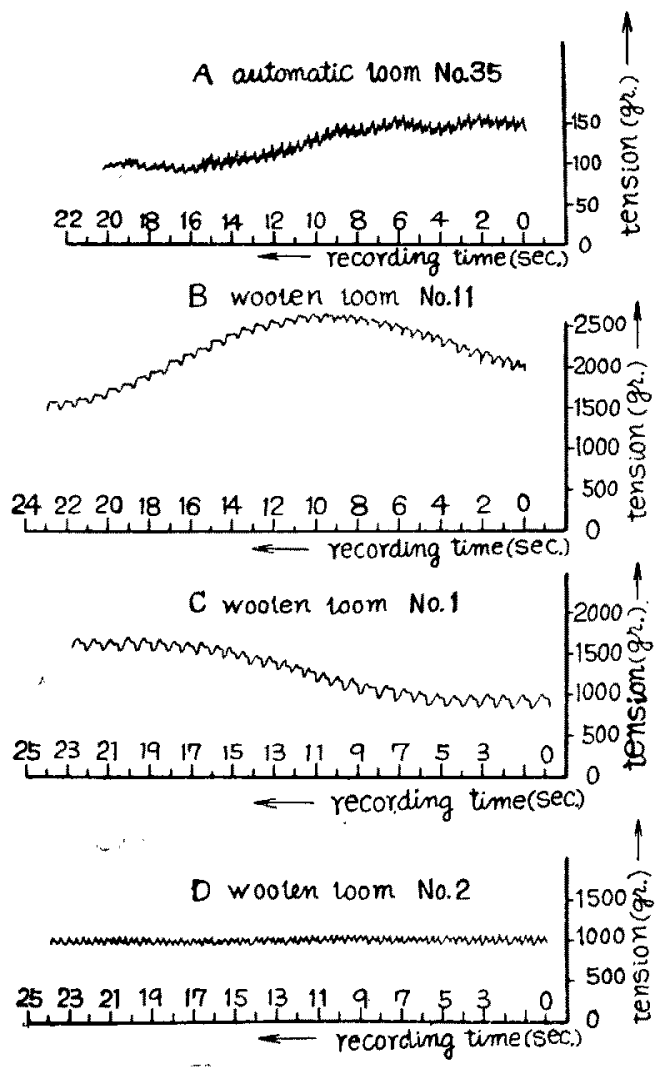

Fig. 3

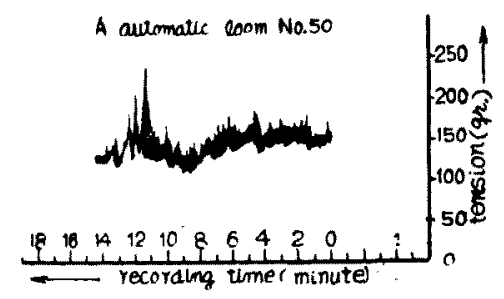

B wolen loom Wo.2

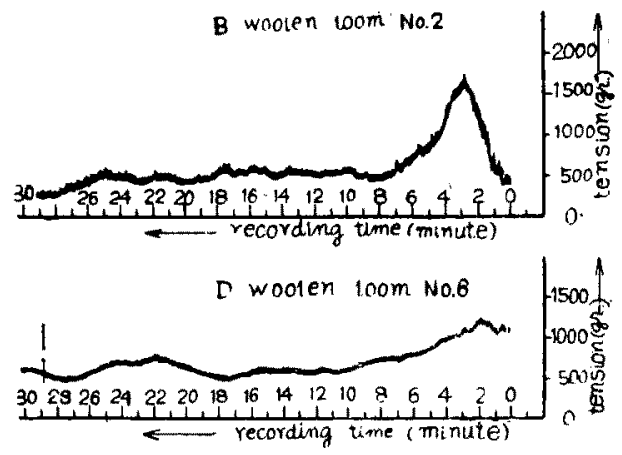

又第 4 楒は同じ織物を製織する多數の織機の經禾張 力の間にどの程度の相量が通常見られるるのかを観測 するため，第2圖の如き各データの最大值によつて比 較したものて，同㮔織機の筫驗における最低值を 100 \%として表示したものであり，囯中の數字はそれぞれ

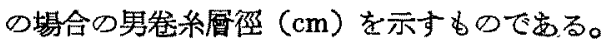

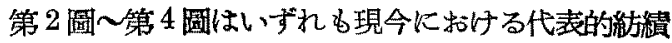
會社の製織中の絓糸㖘力管理の狀況を示するのである が，織機を機箐的に如何に注意して調節を行つてひ， 經系张力をすぺて同一の狀態にすることが如何に困難 なるので雪るかがうかが光るものと思う。

加加る現象は前迅した如く远出不良, 開口の不䄯, 經系の取付狀態, 整經, 經卷の下良, 系の彈性的不济 等が原因で生ずるものと考えられる。及一部の船系に ついてみられるかかる傾向は, 全經系張力心ついて考 えてみても或程度生ずるすのと思われる。郎ち一般に 引通し幅を通して部分的な張力差が可成りあつてる， 全經髣力として考えた場合は或程度本均化されるる のであるから，第 2 圆 一第 4 圖に示寸程顯著な詣向は 現われぬが，一然考慮に值するだけの變化を示するの であつて, ${ }^{3}$ 一たん機上げされて製織工程に人つた經

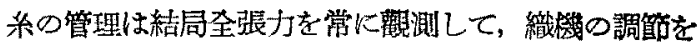
行えばほほ目的を澾し得ることとなるのではなかからう か。

以上の如き䚋察的，㝗驗的見地加ら著者は 
Fig. $\quad 4$

これと關する

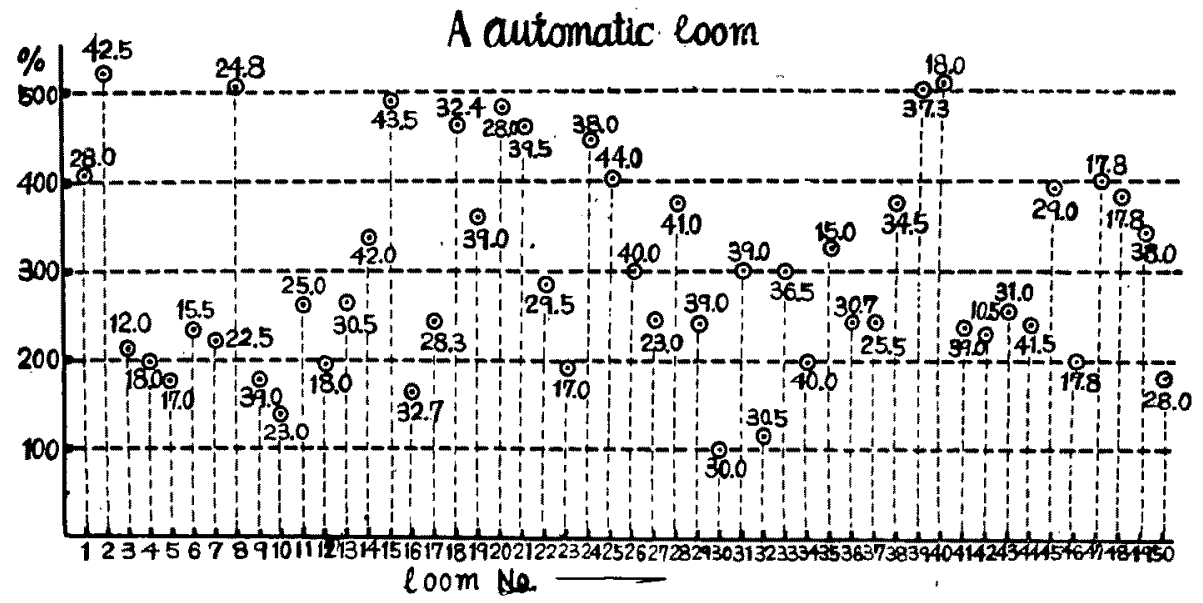

報告の一部は既 に發表したが,4)i 便宜上そその妍點 を再記すれば夷 の如くで要る。 師古第 5 圖火示 す如く, 兩端支 持の梁と考えた バックスト及 はテンションロ ット上比, 各經 紋の張力よっ て生ずる合力が 等分布荷重と乙
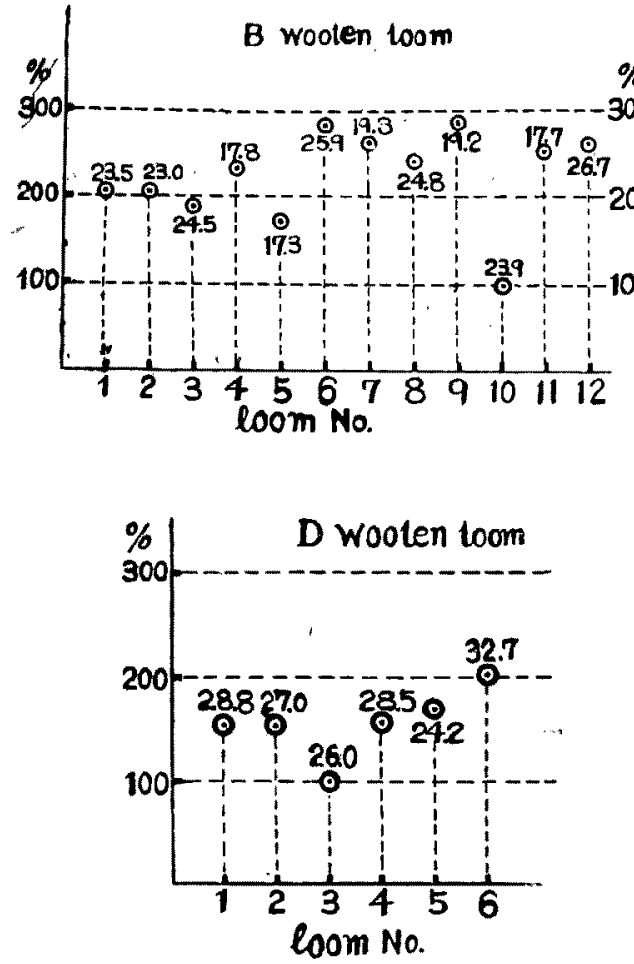

（1）力織機の作重狀態に何等變化を與えない。

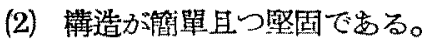

（3）使用方㤼か極めて容易で步る。

等の特徽を有し，織機固有の部品として裝置すること Кよつて，筧際の整織過程に物いて製品を織り乍ら常

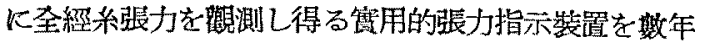
前より色々考察し研究して來た。
C wooten loom

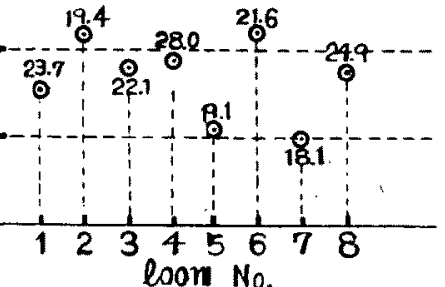

各經系の本均張力を $t$ とすると

$$
P=n t \cos \frac{\theta}{2}=T \cos \frac{\theta}{2}
$$

となる。從つて $P$ を測定すれば $T$ 又は $t$ が求まる

Fig. $\quad 5$

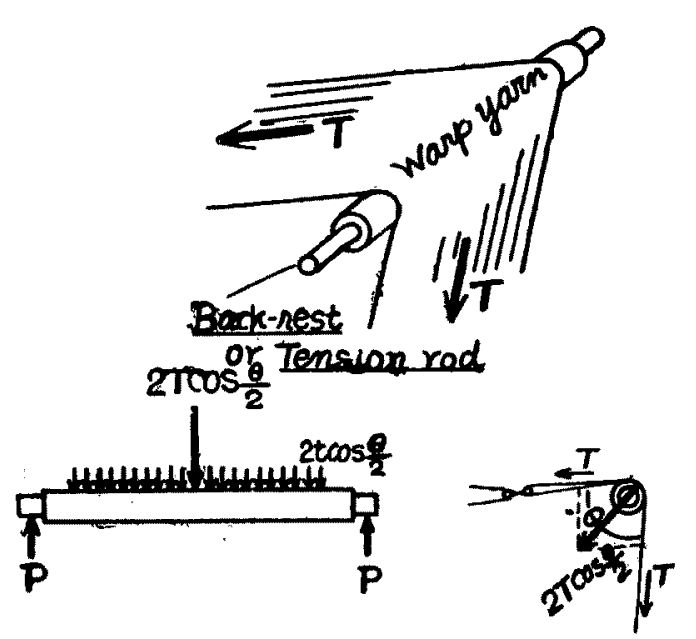


Fig. $\quad 6$

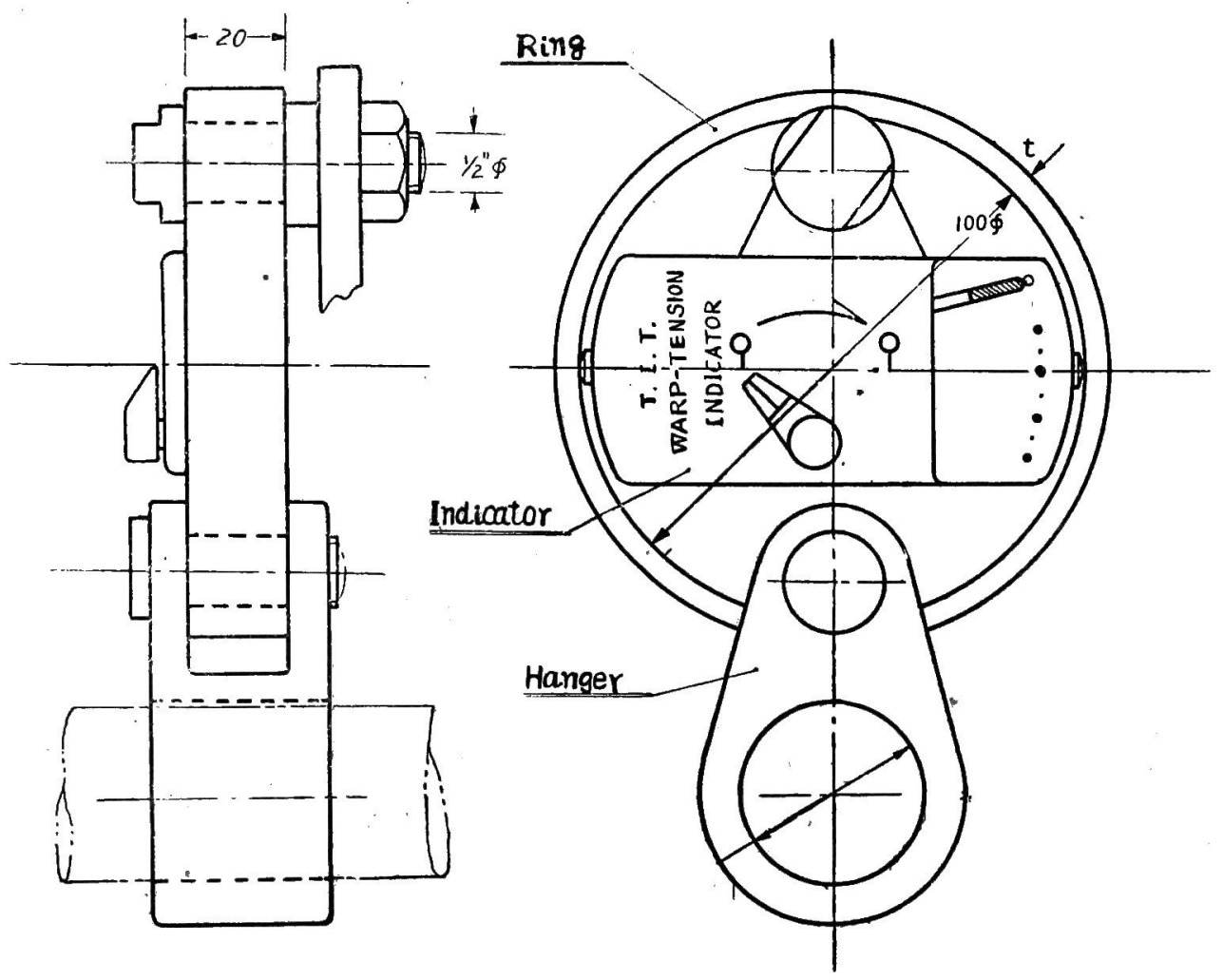

といら思想により，ばね常數の大きな板ばねの微小な る撓みによつて全經糸帰力を检出せんとする装置を試 作し，色々と實驗的研究を行つて來たわけである。

著者はその後, 更に種々檢討し政良研究を行つた結 果，最近活ぱ實用的に完全と思われる經系張力指示裝 置を完成したので，以下その構造，性能等について述 ペてみよう。

\section{2. エ大式經糸張力指示裝置について}

第 6 圖は本張力指示裝置の骨格樋であつて, 第 7 圖 はこれを織機に取付けた狀態を示寸寫貞でむる。

即ち鋼製リングは既報の裝置に抢ける板ばねK相當 するもので，バックレストスはテンションロッドの一 方の軸受又はその主要部になると同時に，張力檢出用 彈性體ともなるれけで, 板ばねや䓪靰ばね比し强度 的にも工作上に怙いてもはるかに適切なるのですり, (1)式の $P$ が第 8 圖の如くその 直俓方向に作用すると その方向の直俓の變化分 $\Delta D_{x}$ は理論的ら求めれば

$$
\Delta D_{x}=0.135 \frac{P R^{3}}{E I}
$$

となる。

但し $R:$ リングの內牛徑 $F:$ ヤング係數

$$
I \text { : 斷面二次モーメント }
$$

從つてこの方向と直角な方向の直俓はこれと等量䧕 け小さくなるから，圖示する如くこの直俓方向に作動

Fig. 7

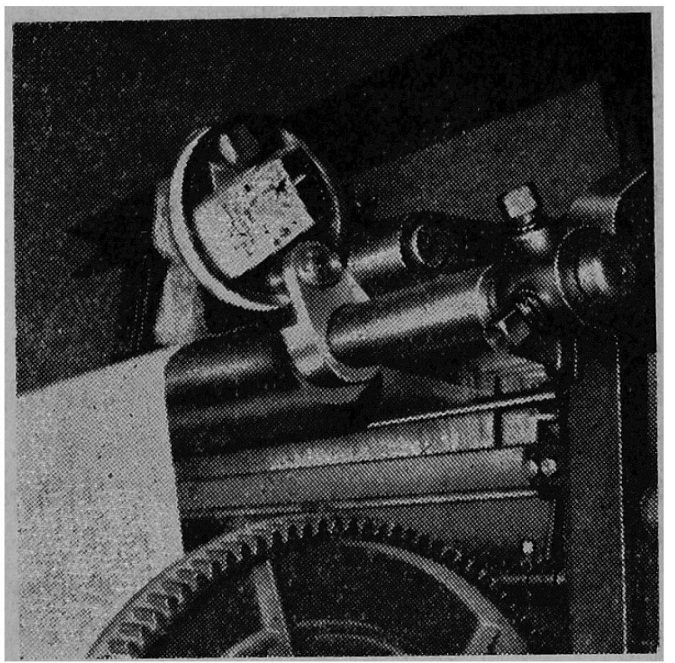


Fig. 8 .

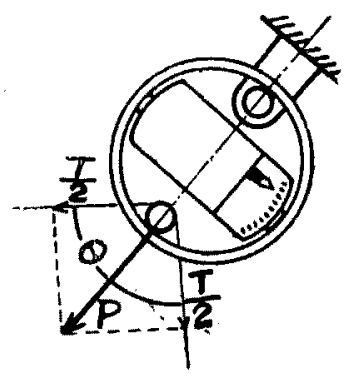

する如く指示器を取 付ければ，その指示 目盛は直ちに $P$ を 示し得るとととなり $T$ を示すことにすな る。試作したるのは 馓力リシグの彈性的 性質を考䆵して，P $=100 \mathrm{~kg}$ 及び $P=$

$200 \mathrm{~kg}$ でそれぞれ $\Delta D_{x}=0.5 \mathrm{~mm}$ になる如く設計した

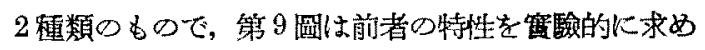
キるのである。

Fig. 9

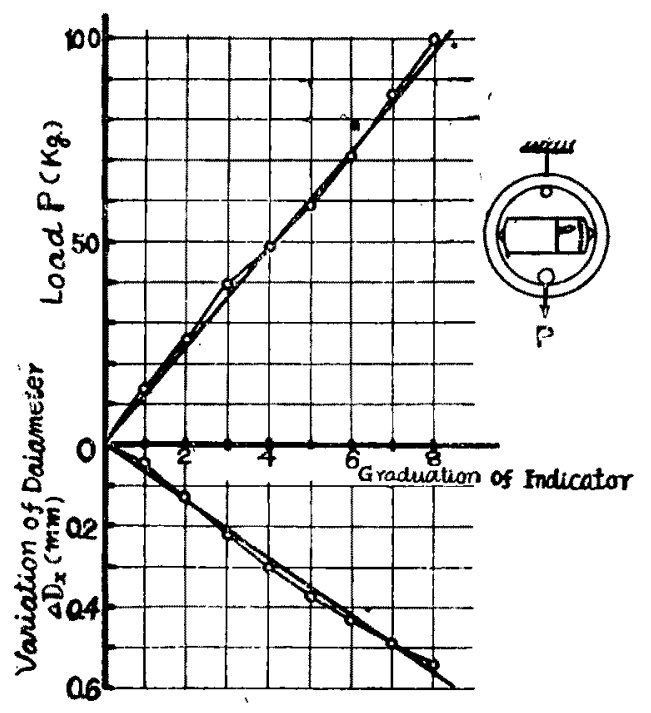

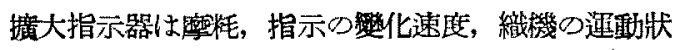

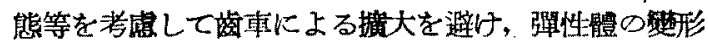
による掘大方法を探用すると同時に堅固でダンビング の比較的大さな構造とし，振動，賣性等による破損， 感度の不正整等の登生を孀力防止出猍るよう特に注意 して設計した。

第 9 凅に示すように指示目盛と $P$ 及び指示目盛と $\Delta D_{x}$ との閣係はそれぞれ極く僅加直線から外れてい， るが，これは指示器自身の特性による影響で西つて， $P$ と $\Delta D$ との關係は完全な直線關係となる。然しな がらこの程度の指示䛇唯は簧際閒題としては何等不都 合はないるのと思われる。

又一般に多くの織機はバックレスト及はテンション ロッドは積椣的的或いは經米張力比基因するトルクに
よつて消極的に廻轉するから，應力リングに直接これ らの軸端を取付けるとリングの摩粍を生じたり指示器 の動播によつて觀測火困嚾を生ずるので，第 6 圆又は 第7圆に示すよらなハンガーを用い，これを介して磨 カリングを作動させることとし，場合によつては軸孔 に更にボールベリングを裝置して勭との接解抵抗に よるこれらの做點を極力取除くように注意した。

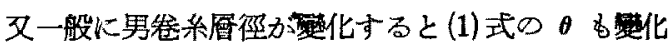
するから，織初めと織終りとでは同一縃䗅力です指 示に鿁差を生ずるものと考完られるが，本張力指示裝 置の指示目盛上K批けるこの誤差は $\theta>170^{\circ}$ の特別の 堨合を除き $2 \sim 5 \%$ 程度であつて，特別の禣正を必管 とする程のことはないものと思われる。

\section{3.むす び}

本張力指示裝置は同じ製品を織る゙多数の織機の經系 張力の狀態をすべて同一のものとし，坞一性の高、製 品を多量に生座せんとする目的に對して一つの管理手 段として用いれば，その品質管理並びに工程管理の面 で可成りの効果が期待出來るものと考えられ，又或る 意味で織物製造に對する織機調笽の規淮が得られるこ とにもなるるのと思われる。即ち從來それぞれの種類 の織物に對する織機各部の調管は，糸の物理的性㭊を 充分考慮しないて機械的にのみ行万傾向方゙娄り，經系 張力はこれによつて充分に管理されるものであるとの 通合が强かつた。しかるに經系張力を理想的に管理す ベく織機各部が如何に理想的に作陲しても，織機各部 の運動と絓系の形との間に時閒的な「ずれ」があり

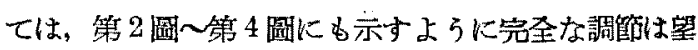
めないので，とかく品質にむらが生じやすく，同じ織 物を多數の織機で織つた場合製品閉には到底均一性と いうものは多く望めないこととなる。かように製織中

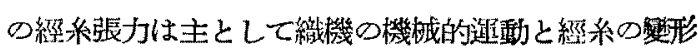
の狀態との影響を共に受けるものであるから製織中の 經系張力の狀態を常に理想的なるのに管理すへく織㙨 を調箇し作動させてするみはしめて均一性の高い織物が 得られることになるるとと思われる。

我々はかかる考え加ら，本指示裝置を用いて製織中 の經系總張力を特別の注意のもとに色々の條件に合致 する如く管理することによつて，如何なる影㘂を織物

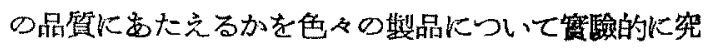

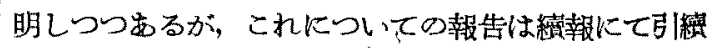
き發表する考えである。終りに本指示装置試作設計に 


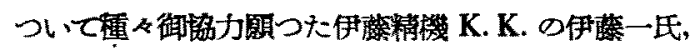

東宗計器 K.K.K對し梁く感謝の意を表する。

文献

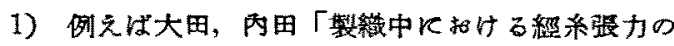

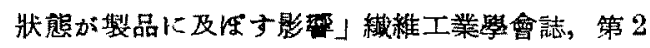
管, 9 號, 1936 年

2）久世，川村「磁䄳現象を磼用せる二，三の測定

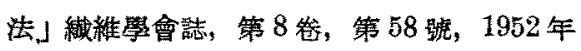

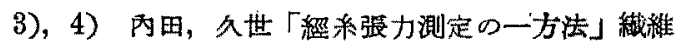
學會誌，第 6 第， 32 號，1950 年

5）碓カリングをその直俓端に括いて分括したと考 えそれぞれの端面と謿く張力，モーメント及び 塑斷力の作用を考虑すれば力學的に簡單に求まる。

（昭和 27 年 9 月 10 日受理）

\section{ギリングがスライバのネップ數及び纎維切断に與える影響 \\ I ネップ数に與える影響}

東京工業大學 石川章一

\section{1. 緒言}

スライバ中のネップは特に羊毛紡續て大きな問題と なるところであり，特にコーミング以後ではこれを除 去する工程がないから，もしギリングによつてネッブ が埥加する（そう考えられている場合するる）とすれ ば閴題となる。本報ではギリングがスライバに與元る

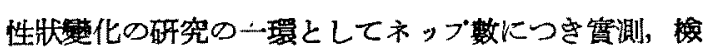
討したるのである。（ネっプの生成原因については別 に詳相に㮝討する必要を認める)

木田氏》は梳毛紡数の前紡工程のネッブに關し，水 力學あるいは坐屈の理諭を考としてネッブを少くす

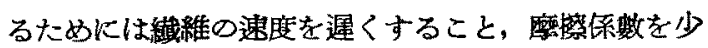
くすること，針を細くすること，スライバを薄く供給 することを操作上必要とし，原料としては短いこと， 直俓の太いこと，引き伸しにくいことを要寸るとの意 見它登表している。

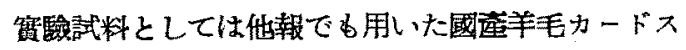
ライベ,メりノカードスライパ, メリノトッブ, スフ カードスライバの 4 種とし，獀測方法は下部から電球 で照らしたガラス板にスライバを㯰き，長さ $40 \mathrm{~cm}$ 間 の*ッブ數をらケ所について數え，10g 掌りのネッブ 數として表示した。

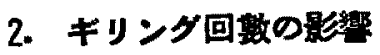

アルサス製前紡第 1 ギル機でドラフト，紡出スライ
バ重量等の諸條件を一定として繰汳し仕掛けた場合の スライバについての結果を第1圆に示す。

國库羊毛カードスライバの場合は(圖中點線)，ギル $1 ， 2 ， 3$ 回と直線的飞增加し，3回て最高值を示し， 以後は活とんど一定でむる。メリノカードスフイバは

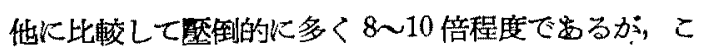

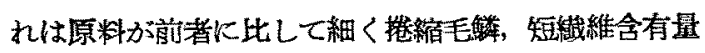
等が多い結果と考光られる。ギリング2 回までは直線 的飞著しく管加し，2回以後は之の差か比較的すくな い。メリノトッブの場合はこれを 1 回するいは 2 回ギ リングするとすこし增加し以後幾分の高下はあるが大

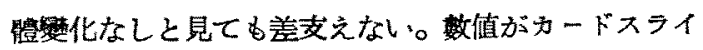
バより著しくすくないのは賞然である。スフの場合は

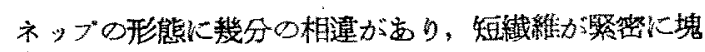
狀をして批らず，織維の束が折れ曲つているようなネ ッブと制定し難いものが工程の初期に多く含まれ，こ れを算入したためギル 1 回で著しい最高値を示し，以 後これが漸次引き伸ばされて消失するため減少しギ リンダ 3 回後任ぶ一定㽡をとつている。

以上各例を通筧してギリング 3 回程度まではネッブ 数は墂加し，カードスライバの場合にその㒄加が渚し い。3 回以後は活メ゙一定し，幾分の減少すら見穴る場 合がある。

ギッング前のネッブはスライバを制造するまでに存 在するものですつて，これは本問題外であるが，ギリ ングによつてネッブが增加するのは何に起因するので 